Note

\title{
Arabidopsis thaliana as a model host for Brevipalpus mite-transmitted viruses
}

\author{
Gabriella Dias Arena르, Pedro Luis Ramos-González ${ }^{1,6}$, Maria Andréia Nunes ${ }^{1}$, Camila Chabi Jesus ${ }^{2,6}$, Renata Faier Calegario ${ }^{3}$, Elliot \\ Watanabe Kitajima ${ }^{4}$, Valdenice Moreira Novelli ${ }^{1}$, Juliana Freitas-Astúa ${ }^{5,6 *}$
}

\author{
${ }^{1}$ Agronomic Institute/Sylvio Moreira Citrus Research Center, \\ Rod. Anhanguera, km 158 - 13490-970 - Cordeirópolis, \\ $\mathrm{SP}$ - Brazil. \\ 2University of São Paulo/ESALQ - Dept. of Soil Science, Av. \\ Pádua Dias, 11 - 13418-900 - Piracicaba, SP - Brazil. \\ ${ }^{3}$ Federal University of Paraná, R. XV de Novembro, 1299 - \\ 80060-000 - Curitiba, PR -Brazil. \\ 4University of São Paulo/ESALQ - Dept. of Plant Pathology \\ and Nematology. \\ ${ }^{5}$ Embrapa Cassava and Fruits, R. Embrapa, s/n - 44380-000 \\ - Cruz das Almas, BA - Brazil. \\ ${ }^{6}$ Biological Institute, Av. Conselheiro Rodrigues Alves, 1252 - \\ 04014-900 - São Paulo, SP - Brazil. \\ *Corresponding author <juliana.astua@embrapa.br> \\ Edited by: Luís Eduardo Aranha Camargo
}

Received October 08, 2015

Accepted March 19, 2016
ABSTRACT: Brevipalpus-transmitted viruses (BTV) are a taxonomically diverse group of plant viruses which severely affect a number of major crops. Members of the group can be subclassified into cytoplasmic (BTV-C) or nuclear type (BTV-N) according to the accumulation sites of virions in the infected plant cells. Both types of BTV produce only local infections near the point of inoculation by viruliferous mites. Features of BTV-plant interactions such as the failure of systemic spread in their natural hosts are poorly understood. In this study we evaluated Arabidopsis thaliana, a model plant commonly used for the study of plant-virus interactions, as an alternative host for BTV. Infection of Arabidopsis with the BTV-N Coffee ringspot virus and Clerodendrum chlorotic spot virus, and the BTV-C Solanum violaefolium ringspot virus, were mediated by viruliferous Brevipalpus mites collected in the wild. Upon infestation, local lesions appeared in 7 to 10 days on leaves of, at least, $80 \%$ of the assayed plants. Presence of viral particles and characteristic cytopathic effects were detected by transmission electron microscopy (TEM) and the viral identities confirmed by specific reverse-transcriptase polymerase chain reaction (RT-PCR) and further amplicon sequencing. The high infection rate and reproducibility of symptoms of the three different viruses assayed validate $A$. thaliana as a feasible alternative experimental host for BTV. Keywords: Clerodendrum chlorotic spot virus, Cilevirus, Solanum violaefolium ringspot virus, Coffee ringspot virus, Dichorhavirus

\section{Introduction}

Plant viruses vectored by species of false spider mites of the genus Brevipalpus [Tenuipalpidae] are known as Brevipalpus-transmitted viruses (BTV) (Kitajima et al., 2014). As a group, BTV affect, at least, 40 plant species ranging from major crops such as citrus and coffee, to economically important cultivated plants such as orchids and passion fruit, and other less significant ornamentals (Bastianel et al., 2010; Kitajima et al., 2010; Ramalho et al., 2014). The BTV-caused citrus leprosis is the main viral disease affecting citrus production in Brazil and is acknowledged to be re-emergent in the Americas (Roy et al., 2015).

BTV are classified as cytoplasmic (BTV-C) or nuclear (BTV-N) according to their replication and accumulation in plant cells. Taxonomically, BTV-C belong to at least one genus, Cilevirus [bipartite (+) single-stranded (ss) RNA] (Locali-Fabris et al., 2012), and possibly to Higrevirus [tripartite (+) ss RNA] (Melzer et al., 2012). BTV-N are classified into the recently created genus Dichorhavirus [bipartite, (-) ssRNA] (Afonso et al., 2016; Dietzgen et al., 2014). Overall, BTV are intriguingly atypical since differently from other plant-virus systems in nature, viral long distance movement is not accomplished in any of their known hosts.

Although BTV were first identified in the early $20^{\text {th }}$ century, molecular information concerning plant-BTV interaction remains barely known. Natural hosts of BTV show large, complex (e.g. citrus, coffee, orchids) (Cai et al., 2015; Xu et al., 2013; Wu et al., 2014; Denoeud et al., 2014) or unknown genomes (e.g. passion fruit) and may require customized installation for their growth and reproduction of BTV-caused diseases. Complexity of the research on the molecular processes involved in plant-BTV pathosystems may be partly bypassed by using appropriate experimental host systems. Arabidopsis thaliana appears as the primary alternative host model for plant-pathogen interaction studies, benefiting from a high-quality curated genome and several resources for reverse genetics approaches (Nishimura and Dangl, 2010).

Recently, we reported Arabidopsis as experimental host for Citrus leprosis virus C (CiLV-C), a BTV-C (Arena et al., 2013; Ramos-González et al., 2016). In this work, Arabidopsis plants were assessed for their capacity to host a wider range of BTV including another BTV-C, Solanum violaefolium ringspot virus (SvRSV), and two BTV-N, Coffee ringspot virus (CoRSV) and Clerodendrum chlorotic spot virus (ClCSV) (Kitajima et al., 2010).

\section{Materials and Methods}

Brevipalpus spp. mites were collected from Solanum violaefolium, Coffea arabica and Clerodendrum speciosum infected with SvRSV, CoRSV and ClCSV, respectively. Plants from wild type $A$. thaliana ecotype Columbia (Col-0) were obtained from the Arabidopsis Biological Resource Center (ABRC) and grown at $22 \pm 2{ }^{\circ} \mathrm{C}$ with a 12-h light cycle in an environmental-controlled growth chamber Adaptis AR A1000 (Winnipeg, Canada). 
Five adult mites collected in plants infected with SvRSV, CoRSV or ClCSV were transferred to each fourweek-old Arabidopsis plant using a small brush. Mites were left on the inoculated leaves and plants were kept under controlled conditions throughout the experiment. Plants were evaluated daily for the development of symptoms.

Viral presence was detected through transmission electron microscopy (TEM) and RT-PCR. To detect cytopathic effects caused by BTV-C and $-\mathrm{N}$, lesioned tissues were processed, fixed in Karnovsky reagent, embedded in Spurr's epoxy resin and examined by TEM (Kitajima et al., 2001). Leaves were assayed by RT-PCR using specific primers for SvSRV (Ferreira et al., 2007), CoRSV (Kitajima et al., 2011) and ClCSV. Total RNA from independent plants inoculated with each virus was extracted using TRIZOL ${ }^{\circledR}$ Reagent (Thermo Scientific, WI, USA). RNA quantification and A260/A280 ratios were estimated using the micro-spectrophotometer NanoDrop ND-8000 (Thermo Scientific). RNA integrity was evaluated in a $1.2 \%$ agarose gel. cDNA corresponding to each sample were generated using RevertAid $\mathrm{H}$ Minus First Strand cDNA Synthesis Kit (Thermo Scientific) as described by the manufacturer. PCRs were performed with $2 \mathrm{uL}$ cDNA, $1 \mathrm{X}$ reaction buffer, $1.8 \mathrm{mM} \mathrm{MgCl}_{2}$, $0.2 \mathrm{mM}$ dNTP mix, $1 \mathrm{U}$ Taq DNA polymerase (Thermo Scientific), $200 \mathrm{nM}$ of specific primers (Table 1) and sterile Milli-Q water for a final volume of $25 \mathrm{uL}$. cDNA from healthy plants were used as negative controls. PCR products were visualized in $1 \%(\mathrm{w} / \mathrm{v})$ agarose gel stained with ethidium bromide.

To confirm viral identity, the amplicons obtained from three plants infected with each BTV were purified using Promega Wizard SV and PCR clean-up system and cloned into pGEM-T-Easy vector (Promega, WI, USA). Ligation products were introduced into Escherichia coli DH5 $\alpha$ by transformation. Plasmids from white colonies were purified using the Promega Wizard ${ }^{\circledR}$ Plus SV Minipreps DNA Purification System and after a digestion with EcoRI restriction enzyme, those containing appropriate fragments were selected. Three individual clones corresponding to each PCR fragment were sequenced in both directions using the BigDye Terminator Cycle Sequencing kit (Thermo Scientific) in an ABI Prism 3730 automated sequencer (Applied Biosystems, CA, USA). Contigs were assembled and compared to GenBank accessions using BLAST search (http://www.ncbi.nlm.nih.gov).

\section{Results and Discussion}

During the last few decades, $A$. thatiana has become the major experimental model for plant biology, including plant-pathogen interactions (Nishimura and Dangl, 2010). Besides the unique characteristics of the plant such as short generation time and small size (allowing for rapid growth and analysis of a large number of individuals in a minimum of space), its genome is compact and completely curated, and a wide mutant collection is available. Much of the current knowledge about the mechanisms underlying plant disease resistance and susceptibility has been discovered studying Arabidopsis pathology and then translated to natural host systems (Nishimura and Dangl, 2010).

We have previously showed that CiLV-C is able to infect Arabidopsis, inducing localized chlorotic symptoms upon infestation with Brevipalpus viruliferous mites (Arena et al., 2013; Ramos-González et al., 2016). In Arabidopsis, symptoms of CiLV-C infection occur in approximately $1 / 3$ of the time they appear in sweet orange (Citrus sinensis), the virus' natural host. Shorter incubation time represents a significant gain on experiments evaluating plant-virus interaction. In this study, we tested the susceptibility of Arabidopsis to SvRSV, a BTV-C and putative member of Cilevirus, CoRSV and ClCSV, two BTV-N and possible members of the genus Dichorhavirus.

After 7 to 10 days of infestation with Brevipalpus spp. viruliferous mites, localized lesions appeared on the inoculated leaves of more than $80 \%$ of the plants in the sets corresponding to each evaluated virus (16 symptomatic /20 infested plants for CoRSV; 4/5 for ClCSV and 4/5 for SvRSV). Arabidopsis plants infected with CoRSV exhibited brown patches not observable in the leaves infected either with ClCSV or SvRSV. However, chlorotic spots on green leaves and green isolated islands on yellow senescent leaves were observed as a common response to the three inoculated viruses (Figure 1A, B, C). This pattern of symptoms resembles that previously described for Arabidopsis infected with CiLV-C (Arena et al., 2013) and also those occurring during infections of SvRSV, CoRSV and ClCSV in their natural hosts (Figure 1D, E and F). However, in natural hosts a necrotic area usually developed in the center of the chlorotic spots. Necrosis was not visible in any of the Arabidopsis plants infected with BTV assayed in this work. Probably, accelerated senescence that takes place on the Arabidopsis infected leaves hampers observation of such

Table 1 - List of primers used to detect Brevipalpus-transmitted viruses (BTV).

\begin{tabular}{|c|c|c|c|c|}
\hline BTV & Primer sequence (5'-3') & Target & Amplicon size (bp) & Reference \\
\hline \multirow{2}{*}{ CoRSV } & GGACCATGAGACAGGAGGTG & ORF RdRp & \multirow{2}{*}{389} & \multirow{2}{*}{ Kitajima et al. (2011) } \\
\hline & CTCTGCCAGTCCTCAATGTG & RNA2 & & \\
\hline \multirow{2}{*}{ SvRSV } & TGTCGAACTTTGGTATGAGTCG & ORF RdRp & \multirow{2}{*}{596} & \multirow{2}{*}{ Ferreira et al. (2007) } \\
\hline & CCGGTTCGTCAAATAACTCC & RNA1 & & \\
\hline \multirow{2}{*}{ CICSV } & ATATCACCGTTTAAGCAAGC & ORF RdRp & \multirow{2}{*}{638} & \multirow{2}{*}{ Unpublished } \\
\hline & TCCTTGTTACAACTCCTTGC & RNA2 & & \\
\hline
\end{tabular}

CoRSV: Coffee ringspot virus; SvRSV: Solanum violaefolium ringspot virus; CICSV: Clerodendrum chlorotic spot virus. 


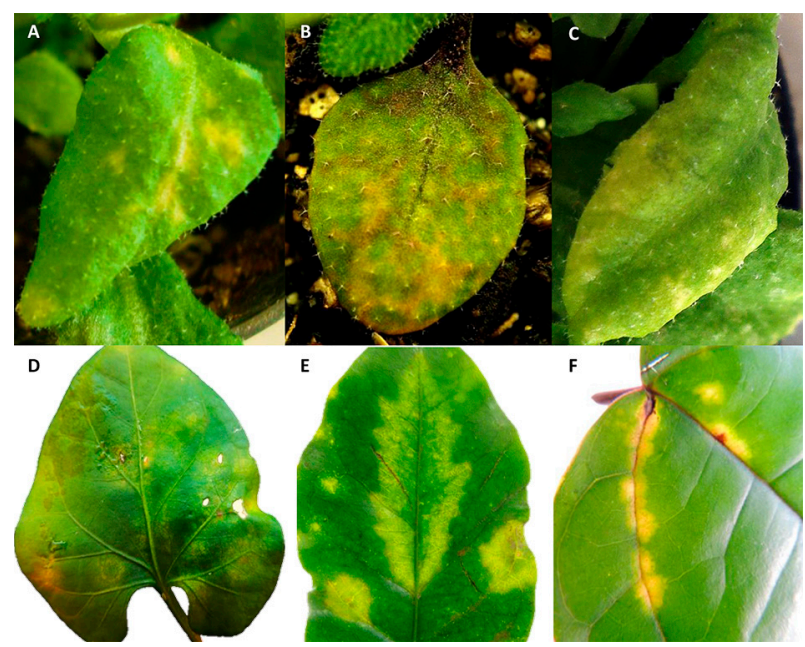

Figure 1 - Symptoms of Brevipalpus-transmitted viruses (BTV) infection on model and natural hosts. In the upper line, Arabidopsis thaliana leaves exhibiting chlorotic spots after infection of Solanum violaefolium ringspot virus (SvRSV) (A), Coffee ringspot virus (CoRSV) (B) and Clerodendrum chlorotic spot virus (CICSV) (C) by Brevipalpus mite - mediated transmission. In the bottom line, leaves of Solanum violaefolium, Coffea arabica and Clerodendrum speciosum infected with SvRSV (D), CoRSV (E) and CICSV (F), respectively.

symptom. Furthermore, as expected, no disease symptoms were observed in the cauline systemic leaves of Arabidopsis, attesting to the typical non-systemic pattern of BTV infection under natural conditions.

Transmission electron microscopy analyses of plants inoculated with SvRSV allowed detecting enveloped bacilliform particles of ca. $50 \times 100 \mathrm{~nm}$ in large pockets of the endoplasmic reticulum of cells of chlorotic lesions. Dense viroplasms were also seen in the cytoplasm of these cells (Figure 2A, B). In contrast, in leaf lesions from plants infected with CoRSV and ClCSV, nonenveloped bacilliform, rod-like virions of ca. $40 \times 110 \mathrm{~nm}$ were observed in both the nucleoplasm and cytoplasm of palisade parenchyma cells. Most particles were arranged perpendicularly to the membranes of the endoplasmic reticulum and the nuclear envelope. Electron lucent viroplasms were detected in the nucleus of CoRSV and ClCSV infected cells, although they were more easily observed in the former case (Figure 2C, D, E, F). In general, virions and cytopathic effects seen in Arabidopsis were identical to those previously described in the natural hosts of SvRSV, CoRSV and ClCSV (Kitajima et al., 2014).

To confirm the identity of viruses present in symptomatic Arabidopsis, RT-PCR tests using specific primers were conducted. As expected, amplicons of approx. 600, 400 and 600 bp were obtained in samples from SvRSV, CoRSV and ClCSV, respectively (Figure 3). Consensi sequences of SvRSV and CoRSV amplicons showed identity values as high as $99 \%$ with sequences obtained from the cognate viruses in the naturally infected hosts available under GenBank accessions number DQ514336 (Solanum

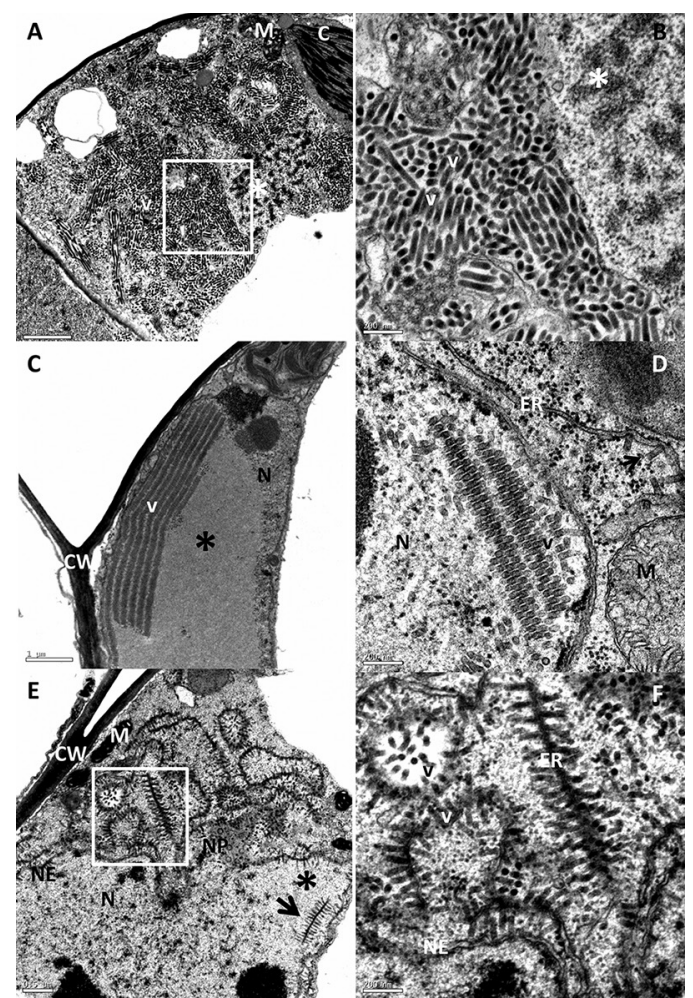

Figure 2 - Micrographs of sections of leaf lesions in Arabidopsis thaliana infected by Solanum violaefolium ringspot virus (SvRSV) (A and $\mathrm{B})$, Coffee ringspot virus (CoRSV) (C and D) and Clerodendrum chlorotic spot virus (CICSV) (E and F). Bacilliform particles (v) and cytoplasmic viroplasma $\left(^{*}\right)$ are present in cells infected by SvRSV, while rod-like particles (v) and nuclear viroplasma $\left({ }^{*}\right)$ can be seen in those infected by CoRSV and CICSV. C: chloroplast; CW: cell wall; M: mitochondrion; NE: nuclear envelope; ER: endoplasmic reticulum.

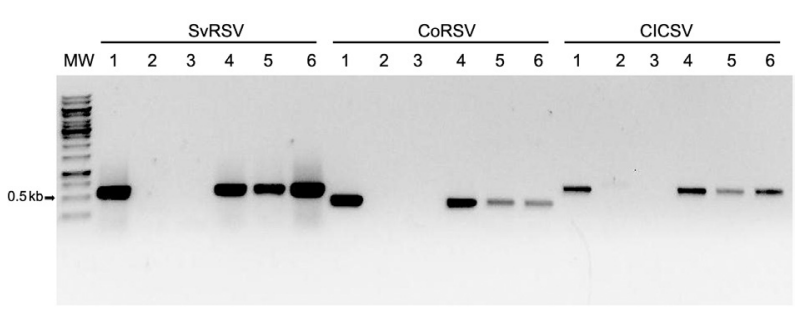

Figure 3 - Agarose gel (1 \%) profile of reverse-transcriptase polymerase chain reaction (RT-PCR) products obtained from plants infected with Solanum violaefolium ringspot virus (SvRSV), Coffee ringspot virus (CoRSV) and Clerodendrum chlorotic spot virus (CICSV). MW: molecular weight marker (GeneRuler 1 kb DNA Ladder, Thermo Scientific); 1: natural hosts infected with each corresponding virus; 2: healthy Arabidopsis thaliana; 3: blank; 4-6: A. thaliana infected with each specific virus. Sizes of the expected amplicons for SvRSV, CoRSV and CICSV are 596, 389 and 638 bp, respectively.

violaefolium ringspot virus replicase-associated protein) and GQ979998 (Coffee ringspot virus isolate Cordeiropolis RNA-dependent RNA polymerase gene). For ClCSV, the 
amplicons showed $100 \%$ with the viral sequence in the Clerodendrum plant used as the viral source. However, these sequences exhibited only $69 \%$ of identity with the sequence previously described for ClCSV isolate ESALQ Piracicaba (HQ853700) (Kitajima et al., 2008), suggesting a wider diversity of BTV-N infecting Clerodendrum plants.

In conclusion, the appearance of localized symptoms in the infected plants, the visualization of typical BTV particles and viroplasms in infected cells, and the confirmation of the identity of the viruses at nucleotide sequence level validated $A$. thaliana as alternative host for both BTV-C and -N. High susceptibility of this plant to mite mediated transmission of BTV and its reduced time for symptom appearance will likely boost research on understanding the interactions involving this peculiar group of plant viruses and their hosts.

\section{Acknowledgements}

The authors wish to thank Luana Rogério, Alex Junior Soares and Thaís Sinico for their technical assistance. This study was supported by FAPESP (São Paulo State Foundation for Research Support) (proc. 2012/18771-0, 2014/00366-8, 2014/08458-9) and CNPq (Brazilian National Council for Scientific and Technological Development) (proc. 375843/2012-4, 481771/2013-1 and 401564/2012-6).

\section{References}

Afonso, C.L.; Amarasinghe, G.K.; Bányai, K.; Bào, Y.; Basler, C.F.; Bavari, S.; Bejerman, N.; Blasdell, K.R.; Briand, F.-X.; Briese, T.; Bukreyev, A.; Calisher, C.H.; Chandran, K.; Chéng, J.; Clawson, A.N.; Collins, P.L.; Dietzgen, R.G.; Dolnik, O.; Domier, L.L.; Dürrwald, R.; Dye, J.M.; Easton, A.J.; Ebihara, H.; Farkas, S.L.; Freitas-Astúa, J.; Formenty, P.; Fouchier, R.A. M.; Fù, Y.; Ghedin, E.; Goodin, M.M.; Hewson, R.; Horie, M.; Hyndman, T.H.; Jiāng, D.; Kitajima, E.W.; Kobinger, G.P.; Kondo, H.; Kurath, G.; Lamb, R.A.; Lenardon, S.; Leroy, E.M.; Li, C.-X.; Lin, X.-D.; Liú, L.; Longdon, B.; Marton, S.; Maisner, A.; Mühlberger, E.; Netesov, S.V.; Nowotny, N.; Patterson, J. L.; Payne, S.L.; Paweska, J.T.; Randall, R.E.; Rima, B.K.; Rota, P.; Rubbenstroth, D.; Schwemmle, M.; Shi, M.; Smither, S. J.; Stenglein, M.D.; Stone, D.M.; Takada, A.; Terregino, C.; Tesh, R.B.; Tian, J.-H.; Tomonaga, K.; Tordo, N.; Towner, J.S.; Vasilakis, N.; Verbeek, M.; Volchkov, V.E.; Wahl-Jensen, V.; Walsh, J.A.; Walker, P.J.; Wang, D.; Wang, L.-F.; Wetzel, T.; Whitfield, A.E.; Xiè, J.T.; Yuen, K.-Y.; Zhang, Y.-Z.; Kuhn, J.H. 2016. Taxonomy of the order Mononegavirales: update 2016. Archives of Virology 161: 2351-60.

Arena, G.D.; Bergamini, M.P.; Tassi, A.D.; Kitajima, E.W.; Kubo, K.S.; Freitas-Astúa, J. 2013. Citrus leprosis virus C infects Arabidopsis thaliana, the model for plant-pathogen interactions. Journal of Plant Pathology 95: 448.

Bastianel, M.; Novelli, V.M.; Kitajima, E.W.; Kubo, K.S.; Bassanezi, R.B.; Machado, M.A.; Freitas-Astúa, J. 2010. Citrus leprosis: centennial of an unusual mite-virus pathosystem. Plant Disease 94: 284-292.
Cai, J.; Liu, X.; Vanneste, K.; Proost, S.; Tsai, W.-C.; Liu, K.-W. Chen, L.-J.; He, Y.; Xu, Q.; Bian, C.; Zheng, Z.; Sun, F.; Liu, W.; Hsiao, Y.-Y.; Pan, Z.-J.; Hsu, C.-C.; Yang, Y.-P.; Hsu, Y.-C.; Chuang, Y.-C.; Dievart, A.; Dufayard, J.-F.; Xu, X.; Wang, J.-Y.; Wang, J.; Xiao, X.-J.; Zhao, X.-M.; Du, R.; Zhang, G.-Q.; Wang, M.; Su, Y.-Y.; Xie, G.-C.; Liu, G.-H.; Li, L.-Q.; Huang, L.-Q.; Luo, Y.-B.; Chen, H.-H.; Van de Peer, Y.; Liu, Z.-J. 2015. The genome sequence of the orchid Phalaenopsis equestris. Nature Genetic 47: 65-72.

Denoeud, F.; Carretero-Paulet, L.; Dereeper, A.; Droc, G.; Guyot, R.; Pietrella, M.; Zheng, C.; Alberti, A.; Anthony, F.; Aprea, G.; Aury, J.M.; Bento, P.; Bernard, M.; Bocs, S.; Campa, C.; Cenci, A.; Combes, M.C.; Crouzillat, D.; Silva, C.; Daddiego, L.; De Bellis, F.; Dussert, S.; Garsmeur, O.; Gayraud, T.; Guignon, V.; Jahn, K.; Jamilloux, V.; Joët, T.; Labadie, K.; Lan, T.; Leclercq, J.; Lepelley, M.; Leroy, T.; Li, L.T.; Librado, P.; Lopez, L.; Muñoz, A.; Noel, B.; Pallavicini, A.; Perrotta, G.; Poncet, V.; Pot, D.; Priyono; Rigoreau, M.; Rouard, M.; Rozas, J.; Tranchant-Dubreuil, C.; VanBuren, R.; Zhang, Q.; Andrade, A.C.; Argout, X.; Bertrand, B.; Kochko, A.; Graziosi, G.; Henry, R.J.; Jayarama; Ming, R.; Nagai, C.; Rounsley, S.; Sankoff, D.; Giuliano, G.; Albert, V.A.; Wincker, P.; Lashermes, P. 2014. The coffee genome provides insight into the convergent evolution of caffeine biosynthesis. Science 345: 1181-1184.

Dietzgen, R.G.; Kuhn, J.H.; Clawson, A.N.; Freitas-Astúa, J.; Goodin, M.M.; Kitajima, E.W.; Kondo, H.; Wetzel, T.; Whitfield, A.E. 2014. Dichorhavirus: a proposed new genus for Brevipalpus mite-transmitted, nuclear, bacilliform, bipartite, negativestrand RNA plant viruses. Archives of Virology 159: 607-619.

Ferreira, P.T.O.; Locali-Fabris, E.C.; Freitas-Astúa, J.; AntonioliLuizon, R.; Gomes, R.T.; Machado, M.A.; Kitajima, E.W. 2007. Characterization of a bacilliform virus isolated from Solanum violaefolium transmitted by the tenuipalpid mites Brevipalpus phoenicis and B. obovatus. Summa Phytopathologica 33: 264269 (in Portuguese, with abstract in English).

Kitajima, E.W.; Chagas, C.M.; Braghini, M.T.; Fazuoli, L.C.; Locali-Fabris, E.C.; Salaroli, R.B. 2011. Natural infection of several Coffea species and hybrids and Psilanthus ebracteolatus by the Coffee ringspot virus (CoRSV). Scientia Agricola 68: 503507.

Kitajima, E.W.; Kondo, H.; Mackenzie, A.; Rezende, J.A.M.; Gioria, R.; Gibbs, A.; Tamada, T. 2001. Comparative cytopathology and immunocytochemistry of Japanese, Australian and Brazilian isolates of orchid fleck virus. Journal of General Plant Pathology 67: 231-237.

Kitajima, E.W.; Kubo, K.S.; Ferreira, P.T.O.; Alcântara, P.K.; Boari, A.J.; Gomes, R.T.; Freitas-Astua, J.; Rezende, J.A.M.; Morais, G.J.; Salaroli, R.B. 2008. Clerodendron chlorotic spot: a disease caused by a nuclear type of Brevipalpus (Acari: Tenuipalpidae)transmitted virus. Scientia Agricola 65: 36-49.

Kitajima, E.W.; Novelli, V.M.; Alberti, G. 2014. Anatomy and fine structure of Brevipalpus mites (Tenuipalpidae) - economically important plant-virus vectors. Part 1. An update on the biology and economical importance of Brevipalpus mites. Zoologica 160: 1-10.

Kitajima, E.W.; Rodrigues, J.C.V.; Freitas-Astúa, J. 2010. An annotated list of ornamentals naturally found infected by Brevipalpus mitetransmitted viruses. Scientia Agricola 67: 348-371. 
Locali-Fabris, E.C.; Freitas-Astúa, J.; Machado, M.A. 2012. Genus Cilevirus. p. 1139-1142. In: King, A.M.Q.; Adams, M.J.; Carstens, E.B.; Lefkowitz, E.J., eds. Virus taxonomy: classification and nomenclature of viruses: Ninth Report of the International Committee on Taxonomy of Viruses. Elsevier, San Diego, CA, USA.

Melzer, M.J.; Sether, D.M.; Borth, W.B.; Hu, J.S. 2012. Characterization of a virus infecting Citrus volkameriana with citrus leprosis-like symptoms. Phytopathology 102: 122-127.

Nishimura, M.T.; Dangl, J.L. 2010. Arabidopsis and the plant immune system. Plant Journal 61: 1053-1066.

Ramalho, T.O.; Figueira, A.R.; Sotero, A.J.; Wang, R.; Geraldino Duarte, P.S.; Farman, M.; Goodin, M.M. 2014. Characterization of Coffee ringspot virus-Lavras: a model for an emerging threat to coffee production and quality. Virology 464-465: 385-396.

Ramos-González, P.L.; Chabi-Jesus, C.; Guerra-Peraza, O.; Breton, M.C.; Arena, G.D.; Nunes, M.A.; Kitajima, E.W.; Machado, M.A.; Freitas-Astúa, J. 2016. Phylogenetic and Molecular Variability Studies Reveal a New Genetic Clade of Citrus leprosis virus C. Viruses. 8: 153.

Roy, A.; Hartung, J.S.; Schneider, W.L.; Shao, J.; León, M.G.; Melzer, M.J.; Bear, J.J.; Otero-Colina, G.; Bauchan, G.R.; Ochoa, R.; Brlansky, R.H. 2015. Role bending: complex relationships between viruses, hosts and vectors related to citrus leprosis, an emerging disease. Phytopathology 105: 1013-1025.
Wu, G.A.; Prochnik, S.; Jenkins, J.; Salse, J.; Hellsten, U.; Murat, F.; Perrier, X.; Ruiz, M.; Scalabrin, S.; Terol, J.; Takita, M.A.; Labadie, K.; Poulain, J.; Couloux, A.; Jabbari, K.; Cattonaro, F.; Del Fabbro, C.; Pinosio, S.; Zuccolo, A.; Chapman, J.; Grimwood, J.; Tadeo, F.R.; Estornell, L.H.; Muñoz-Sanz, J.V; Ibanez, V.; Herrero-Ortega, A.; Aleza, P.; Pérez-Pérez, J.; Ramón, D.; Brunel, D.; Luro, F.; Chen, C.; Farmerie, W.G.; Desany, B.; Kodira, C.; Mohiuddin, M.; Harkins, T.; Fredrikson, K.; Burns, P.; Lomsadze, A.; Borodovsky, M.; Reforgiato, G.; Freitas-Astúa, J.; Quetier, F.; Navarro, L.; Roose, M.; Wincker, P.; Schmutz, J.; Morgante, M.; Machado, M.A.; Talon, M.; Jaillon, O.; Ollitrault, P.; Gmitter, F.; Rokhsar, D. 2014. Sequencing of diverse mandarin, pummelo and orange genomes reveals complex history of admixture during citrus domestication. Nature Biotechnology 32: 656-662.

Xu, Q.; Chen, L.-L.; Ruan, X.; Chen, D.; Zhu, A.; Chen, C.; Bertrand, D.; Jiao, W.-B.; Hao, B.-H.; Lyon, M.P.; Chen, J.; Gao, S.; Xing, F.; Lan, H.; Chang, J.-W.; Ge, X.; Lei, Y.; Hu, Q.; Miao, Y.; Wang, L.; Xiao, S.; Biswas, M.K.; Zeng, W.; Guo, F.; Cao, H.; Yang, X.; Xu, X.-W.; Cheng, Y.-J.; Xu, J.; Liu, J.-H.; Luo, O.J.; Tang, Z.; Guo, W.-W.; Kuang, H.; Zhang, H.-Y.; Roose, M.L.; Nagarajan, N.; Deng, X.-X.; Ruan, Y. 2012. The draft genome of sweet orange (Citrus sinensis). Nature Genetic 45: 59-66. 